The

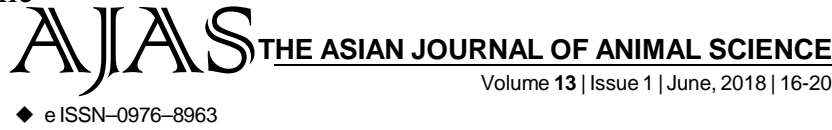

DOI : 10.15740/HAS/TAJAS/13.1/16-20

Visit us | www.researchjournal.co.in

RESEARCH ARTICLE........

\title{
Effect of integrated fish cum duck farming system on productivity of fish ponds
}

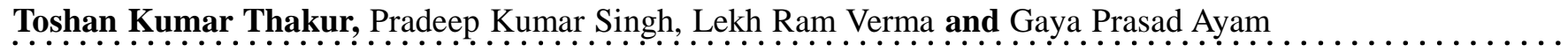

Author for Corresponding -

Toshan Kumar Thakur

Krishi Vigyan Kendra (I.G.A.U.),

Bastar, Jagdalpur (C.G.) India

Email : toshan.thakur@

gmail.com

See end of the article for

Coopted authors'
ABSTRACT...... The experiment was conducted at Bastar disrtict of Chhattisgarh to assessment of fish cum duck farming system on physico-chemical, biological parameters of pond ecosystem and overall fish production in the ponds. This trial was conducted during three successive years 2014-2016 for the period of 8 months. The pond was stocked with fingerlings @6000/ha of indian major carps (Catla catla, Labeo rohita, Cirrhinus mrigala in a ratio of 4:3:3) to utilize the maximum energy in the pond through polyculture. The Muscovy (Local name-Naghansh, S.N. - Cairina moschata) breed of ducks was used for the integrated system to fulfill the purpose of obtaining the meat and for deliver the excreta into the ponds during wild grazing. Under such cultural practice at village level no supplementary feed was given to the fish while the ducks were fed with fresh kitchen leftovers and agricultural by products as kanki (broken cereal grains), kodha (rice bran) which are easily available commodities in rural areas. The study revealed that water quality parameters i.e. $\mathrm{pH}$, dissolved oxygen, alkalinity were significantly higher in integrated pond than control pond (without ducks). Further plankton levels (Phyto and zooplankton) were also improved considerably in integrated pond. Indian major carps in the integrated ponds exhibited better body weight than the control pond. Better growth rate in fishes was contributed to a yield of 1.980 tonnes/ha/ year with integration of ducks in fish pond whereas 1.052 tonnes/ha/year yields were observed in the control pond. The results conclude that integrated fish cum duck farming is more profitable than farming fish alone with no inputs under rural conditions of Chhattisgarh.

KEY WORDS...... Fish cum duck farming, Plankton, Village pond

HOW TO CITE THIS ARTICLE - Thakur, Toshan Kumar, Singh, Pradeep Kumar, Verma, Lekh Ram and Ayam, Gaya Prasad (2018). Effect of integrated fish cum duck farming system on productivity of fish ponds. Asian J. Animal Sci.,13(1): 16-20. DOI : 10.15740/HAS/TAJAS/13.1/16-20. Copyright@ 2018:HindAgri-Horticultural Society.

ARTICLE CHRONICLE - Received : 11.04.2018; Revised : 15.05.2018; Accepted : 25.05.2018 